ment with the known seismic refraction and heat flow data. His group believes that the region is the site of a late Precambrian rift which was reactivated in the Mesozoic to form an aulacogen and its model involves thinning of the upper crust and an increase in density in the lower crust. The magnetic low is accounted for by either an isotherm upwarp or, less likely, a lithological variation in the crust. Mayhew's
(Business and Technological Systems, Inc.) magnetization model for the United States, derived from Magsat scalar data, had much better resolution than that using POGO data.

Although preliminary, the results discussed at the meeting indicate that separation of the measured field into its core, crustal and external 'components' is being achieved. The newest discipline, inter- pretation of long-wavelength crustal fields in terms of a geological/geophysical model, promises to contribute significantly to our understanding of the Earth's crust. In the older disciplines of main-field modelling and studies of external fields, there are significant new developments in both analytical techniques and in our understanding of the physics of the field sources.

\title{
The East Asian jigsaw puzzle — Pangaea at risk?
}

\section{from Neville Haile}

UNTIL fairly recently, reconstructions of the world palaeogeography followed Wegener in showing Eurasia, excluding the Indian subcontinent, as a single block, with the Malay Peninsula and part or all of the Indonesian Archipelago depending from it and looking rather vulnerable ${ }^{1,2}$. Other world palaeogeographical maps simply omit South-east Asia and most of China (see the figure) ${ }^{3,4}$.

The suggestion that South-east Asia, or part of it, was initially separate from mainland Asia, to which it later became welded, dates back at least to Wing Easton $^{5}$ in 1921. More recent variations show South-east Asia (with or without parts of China) in Palaeozoic or early Mesozoic times attached to various parts of Gondwana, or to Laurentia in the same configuration as at present, or detached from both ${ }^{6,7}$. Argand's ${ }^{8}$ idea that the rest of mainland East Asia south of the Siberian craton may be an aggregate of a number of blocks, which have had a separate history and become welded together after colliding, has been recently revived ${ }^{9.10}$ on the basis of new and more detailed maps produced by Chinese geologists, showing belts of calcalkaline rocks and ophiolites interpreted as fossil subduction zones" ${ }^{11}$. A recent Sino-American review" 12 asserts: "In a nutshell, China is the product of the processes which led to gradual accretion onto the Siberian craton of a number of island arc systems and the capturing of relatively small continents. This process continued with the collision of the Indian subcontinent with Asia'. Palaeomagnetic methods are ideally suited to test these hypotheses, delineate the pieces of the jigsaw puzzle and trace their movements through geological time, but hitherto palaeomagnetic evidence from China has been sparse and inconclusive. Moreover, this lack of information from China makes it difficult to interpret and integrate the data available from the peripheral areas of Siberia, Korea, Japan and the Indian subcontinent, and South-east Asia $^{13}$.

Neville Haile is at Robertson Research International, Llanrhos, UK.

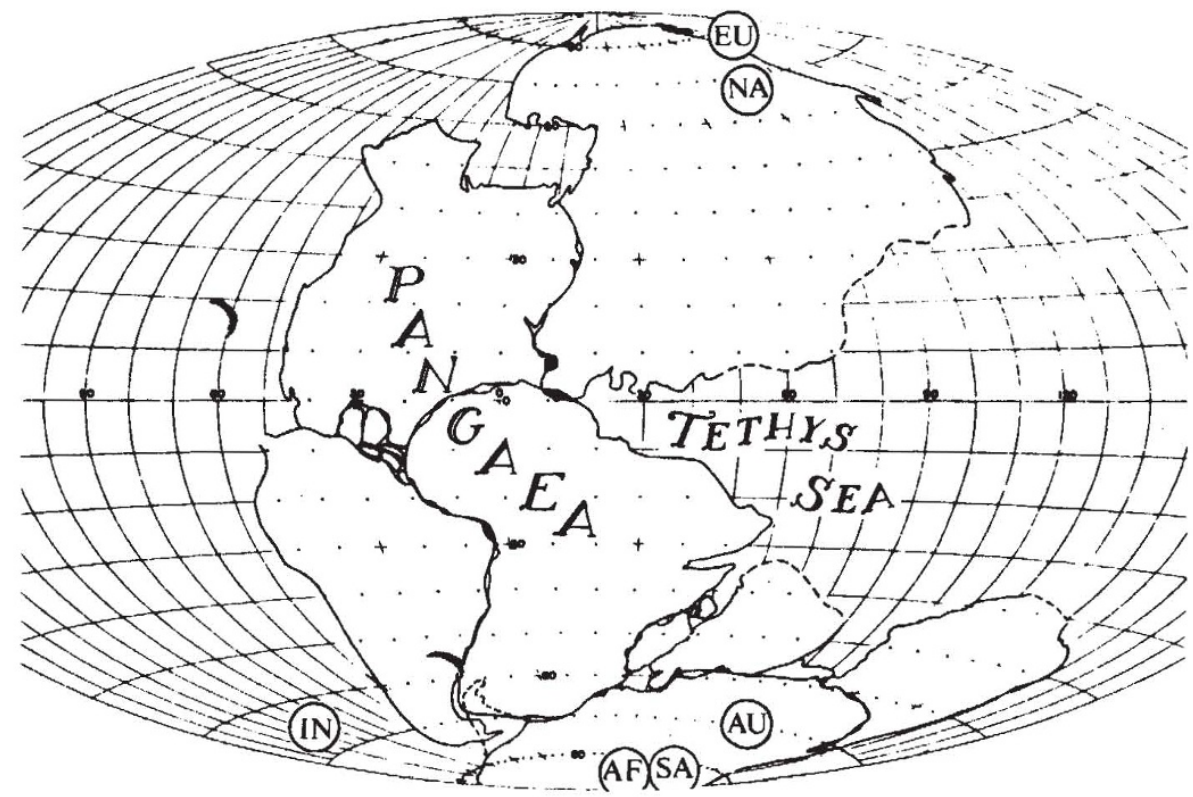

Reconstruction of the continents into the universal landmass of Pangaea as of the end of the Permian, 225 Myr ago - the 'classical' concept of Wegener in a version by Dietz and Holden ${ }^{3}$. Where were East and South-east Asia?

The paper by McElhinny et al. (this issue of Nature, page 212) is significant in showing that rocks from the same system (Permian) on two of the postulated tectonic blocks of China show different palaeomagnetic vectors, supporting the idea that in the Permian they were separated from each other and from other parts of Asia for which there is published data. The authors' geographical reconstruction for the Permian shows four continental blocks drifting independently in a proto-Pacific Ocean, waiting to collide with and be welded to the mainland (India and Qinhai-Tibet being off-stage, presumably to the south, forming part of Gondwana). If this is correct, then Wegener's percipient idea, now orthodox theory, that all the continents were joined into a single supercontinent of Pangaea in the Permian, is an over-simplification.

The authors' model is only one of several that could satisfy the data. Ideally the next step should be an attempt to establish palaeomagnetic vectors from all geological systems over wide areas of East and South-east Asia in order to define apparent polar wander curves for each of the postulated blocks, and to integrate the results with evidence from structural geology, palaeoclimatology, fossils and (for the late Mesozoic and Cenozoic) ocean-floor spreading history. To achieve this would seem to call for a major cooperative effort - an international decade of palaeogeography?

1. Wilson, J.T. Sci. Am. 208(4), 86 (1963).

. Smith A.G. \& Briden, J.C. Mesozoic and Cenozoic Palaeocontinental Maps (Cambridge University Press, 1977).

3. Dietz, R.S. \& Holden, J.C. J.geophys. Res. 75, 4939 (1970).

Irving, E. Nature 270, 304 (1977).

5. Wing Easton, cited by du Toit, A.L.. in Our Wandering Continents - an Hypothesis of Continental Drifting, 126 (Oliver and Boyd, Edinburgh, 1937).

6. Scotese, C.R., Kambach, R.K., Barton, C., van der Voo, R. \& Ziegler, A.M. J. Geol. 87, 127 (1979).

7. Haile, N.S. Earth planet. Sci. Lett. 48, 233 (1980).

8. Argand, E. C.r. 13th int. geol. Congr. 1922, Brussels, 1, 171 (1942)

9. Burett, C.F. Earth planet. Sci. Lett. 21181 (1974).

10. Terman, M.J. Abstr. Bull. Am. Ass. petrol. Geol. 62, 12,2513 (1978).

11. Huang, Chi-Ching (T.K.) Eclog. geol. Helv. 71, 611 (1978).

2. Bally, A.W et al. U.S. geol. Survey Open-file Rep. 80-501, Reston, Virginia (1980)

13. Haile, N.S. in Paleoreconstruction of the Continents, 129 (American Geophysical Union Geodynamics Series 2, 1981). 